\title{
Allelopathic effect of invasive plants (Eriochloa villosa, Asclepias syriaca, Fallopia $x$ bohemica, Solidago gigantea) on seed germination
}

\author{
Arnold Szilágyi - László Radócz - Tamás Tóth \\ University of Debrecen, Faculty of Agricultural, Food Sciences and Environment Management, \\ Plant Protection Institute, Debrecen \\ szilagyi.arnold@agr.unideb.hu
}

\begin{abstract}
SUMMARY
The aim of this study was to determine the allelopathic potential of invasive species woolly cupgrass (Eriochloa villosa), common milkweed (Asclepias syriaca), bohemian knotweed (Fallopia $x$ bohemica), and giant goldenrod (Solidago gigantea Ait.) on germination crop (Lepidium sativum L.). Experiments were conducted under laboratory conditions to determine effect of water extracts in petri dish bioassay. Water extracts from fresh biomass (leaves and stem) of invasive weeds in concentrations of 4 and $8 \mathrm{~g} / 100 \mathrm{ml}$ were investigated. All invasive plants showed allelopathic effect on germination. In giant goldenrod stem water extract experiment, allelopathic effect was less pronounced. The cress germination was greatly suppressed with the woolly cupgrass, common milkweed and the giant goldenrod. The experiment showed that the seed germination depended on the concentrations and the plant material used (leaves and stem).
\end{abstract}

Keywords: allelopathic effect, water extract, invasive plants, Eriochloa villosa, Asclepias syriaca, Fallopia X bohemica, Solidago gigantea

\section{INTRODUCTION}

This study was targeted to investigate the allelopathic effects of various weeds extracts on seed germination. "Biochemical inhibition" theory was confirmed in 1937 by Molisch, who introduced the scientific term of ,allelopathy". The word "allelopathy" is derived from two separate words. These are allelon meaning "one another", and pathos meaning "to suffer". Allelopathy refers to the inhibition of a species to another by using chemicals.

Weed seed germination inhibition and growth suppression which can be attributed to allelopathy is highly important and can be considered as a possible alternative, non-chemical weed management strategy (Macias 1995, Asghari and Tewari 2007). Beside crops, weed species with high inhibitory effect also have the potential to be used in control of other weeds (Qasem and Foy 2001, Galzina et al. 2011). Inhibitory" substances are released into the environment where it affects the development and growth of surrounding plants (Ferguson et al. 2013). Active secretions are produced by live organs of the plant, and the passive, come from the dead organs in the course of decomposition (Chirilă 2001). Allelopathy is a naturally occurring phenomenon which refers to any direct or indirect effect, positive or negative of a plant to the other by the release of chemical compounds into the environment (Delabays et al. 2004). The structure and mode of action of allelopathic substances are different, due to this fact they can be used for future development of herbicides (Uludag et al. 2005, Weston 2005).

The aim of this study was to determine allelopathic effect of water extracts from biomass of Eriochloa villosa (ERIVI), Asclepias syriaca (ASCSY), Fallopia $x$ bohemica (REYBO), Solidago gigantea (SOOGI) on germination (lettuce) in Petri dishes.
It was concluded that some of the weed extracts tested in this study could be used as inhibitor while others could be used as stimulator for the crops. In this work the effects of water extract of some invasive plants on germination of cress (Lepidium sativum L.) plant were studied under laboratory conditions.

\section{MATERIALS AND METHODS}

The research was conducted in the laboratories of the University of Debrecen, Faculty of Agricultural, Food Sciences and Environment Management, Plant Protection Institute.

As the first steps of the research collection of the invasive plants, were exactly done in august 2017. The fresh plant samples were stored in a freezer until the test. Preparation of the extracts from the invasive plants was done in the following way: the leaves and stem shredded and we measured $4 \mathrm{~g}$ and $8 \mathrm{~g}$ samples (Figure 1). $100 \mathrm{ml}$ of distilled water were added to the samples. The test plant was cress (Lepidium sativum L.).

Cress seeds were placed on a layer of filter paper in a Petri dish (20 seeds/dish) with $10 \mathrm{ml}$ of the extract. The Petri dishes were placed in the laboratory at natural light and $20 \pm 2{ }^{\circ} \mathrm{C}$ for 2 days (Figure 2 ).

The experiments were repeated 3 times. Germination percentage was calculated as $G$ $($ Germination, $\%)=($ Germinated seed/Total seed $) \times 100$. The success of germination was characterized by the percentage of germinated seeds (germination \%) $(n=20)$. The effect of the extracts with different concentrations (4 and $8 \mathrm{~g} / 100 \mathrm{ml}$ ) and controls was compared by nonparametric Kruskall-Wallis test because our data did not fit the assumptions of parametric tests. If we find significant differences and in case of comparison of different organs (steam and leaf) the groups were compared with Mann-Whitney U-test. The statistical analysis was carried out with SPSS 21 program package (Ketskeméty et al. 2011). 
Figure 1: Samples preparing and making water extract
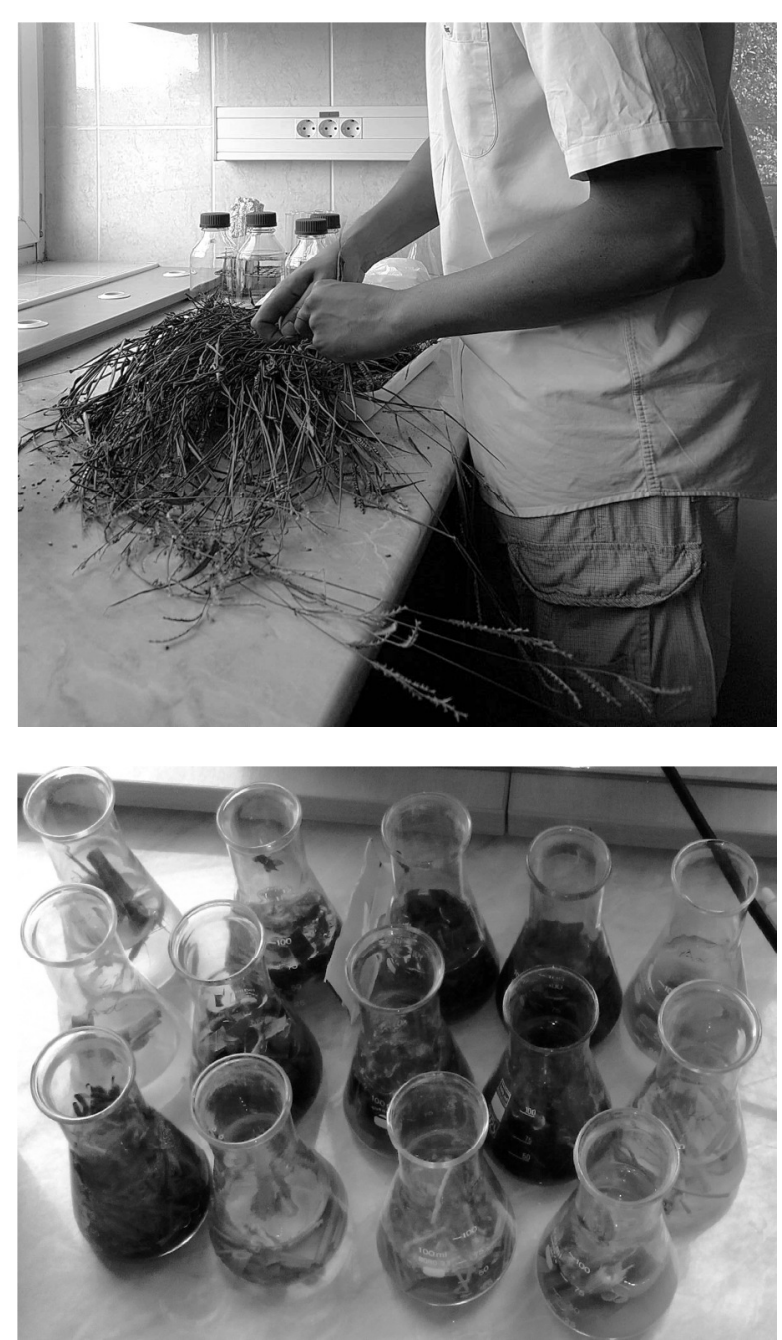

Source: Szilágyi (2017)

Figure 2: The research setting

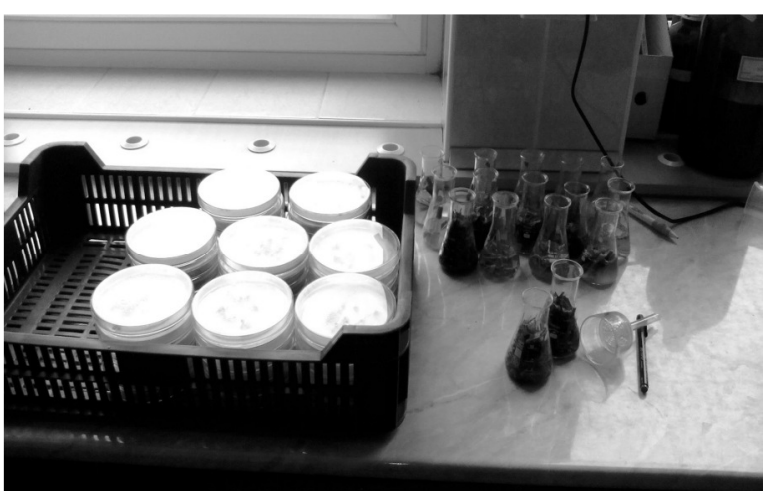

Source: Szilágyi (2017)

\section{RESULTS AND DISCUSSION}

\section{The effects of stem extracts}

Asclepias syriaca water extract had various effects on germination of crops in petri dish bioassay. Germination was inhibited in cress test species, however only higher concentrations showed significant effect compare to the control $(\mathrm{K}-\mathrm{W}: \mathrm{H}=$ 6.72, $\mathrm{df}=2, \mathrm{n}=9, \mathrm{p}=0.0347$ ).

Similarly, Eriochloa villosa was differently affected with the extract application. Germination was inhibited in cress test species, the $4 \mathrm{~g} / 100 \mathrm{ml}$ and the $8 \mathrm{~g} / 100 \mathrm{ml}$ stem water extract were not significantly different, but significantly deviated than from control extract $(K-W: H=6.22, d f=2, n=9, p=0.0446)$.

The mean final percentages of germination were significantly different among the $8 \mathrm{~g} / 100 \mathrm{ml}$ Fallopia $x$ bohemica stem extract concentrations $(\mathrm{K}-\mathrm{W}: \mathrm{H}=$ 7.62, $\mathrm{df}=2, \mathrm{n}=9, \mathrm{p}=0.0221$ ).

4 and $8 \mathrm{~g} / 100 \mathrm{ml}$ Solidago gigantea extract had various effects on germination, but these were not significant $(\mathrm{K}-\mathrm{W}: \mathrm{H}=5.62, \mathrm{df}=2, \mathrm{n}=9, \mathrm{p}=0.0600)$.

Solidago gigantea had an effect on germination but did not differ significantly $(\mathrm{K}-\mathrm{W}: \mathrm{H}=5.62, \mathrm{df}=2$, $\mathrm{n}=9, \mathrm{p}=0.0600$ ) (Figure 3).

\section{The effects of leaf extracts}

4 and $8 \mathrm{~g} / 100 \mathrm{ml}$ concentrations of Asclepias syriaca extract showed allelopathic effect on germination of L. sativum. Germination was inhibited in test species, however either concentrations showed significant effect compare to the control $(\mathrm{K}-\mathrm{W}: \mathrm{H}=$ 6.13, $\mathrm{df}=2, \mathrm{n}=9, \mathrm{p}=0.0465$ ).

Similarly, Eriochloa villosa was differently affected with the extract application. With the increase of extract concentration the germination significantly decreased compared to the control $(\mathrm{K}-\mathrm{W}: \mathrm{H}=7.51$, $\mathrm{df}=2, \mathrm{n}=9, \mathrm{p}=0.0234)$. The $4 \mathrm{~g} / 100 \mathrm{ml}$ and the $8 \mathrm{~g} / 100$ $\mathrm{ml}$ leaf water extract were significantly different.

The mean final percentages of germination were significantly different among Fallopia $x$ bohemica leaf extract concentrations compare to the control, but the 4 and $8 \mathrm{~g} / 100 \mathrm{ml}$ were not significant $(\mathrm{K}-\mathrm{W}: \mathrm{H}=6.22$, $\mathrm{df}=2, \mathrm{n}=9, \mathrm{p}=0.0446)$.

4 and $8 \mathrm{~g} / 100 \mathrm{ml}$ Solidago gigantea leaf water extract had various effects on germination. Both values were significantly different from the control, and the $4 \mathrm{~g} / 100 \mathrm{ml}$ and the $8 \mathrm{~g} / 100 \mathrm{ml}$ leaf water extract were significantly different $(\mathrm{K}-\mathrm{W}: \mathrm{H}=7.57$, $\mathrm{df}=2, \mathrm{n}=9, \mathrm{p}=0.0226$ ) (Figure 4). 
Figure 3: The effects of stem extracts to examined species

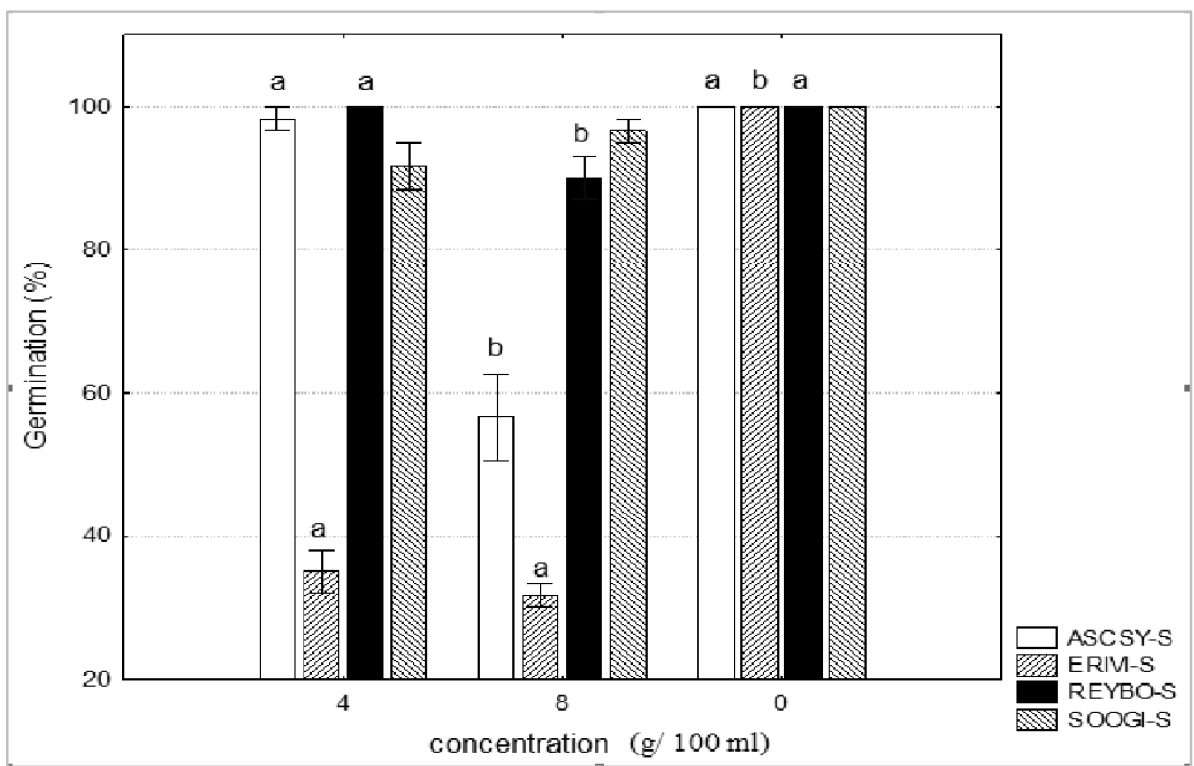

Source: Szilágyi (2017)

Note: small letters show the statistical differences based on Mann-Whitney U- test $(\mathrm{p}<0.05)$.

Figure 4: The effects of leaf extracts to examined species

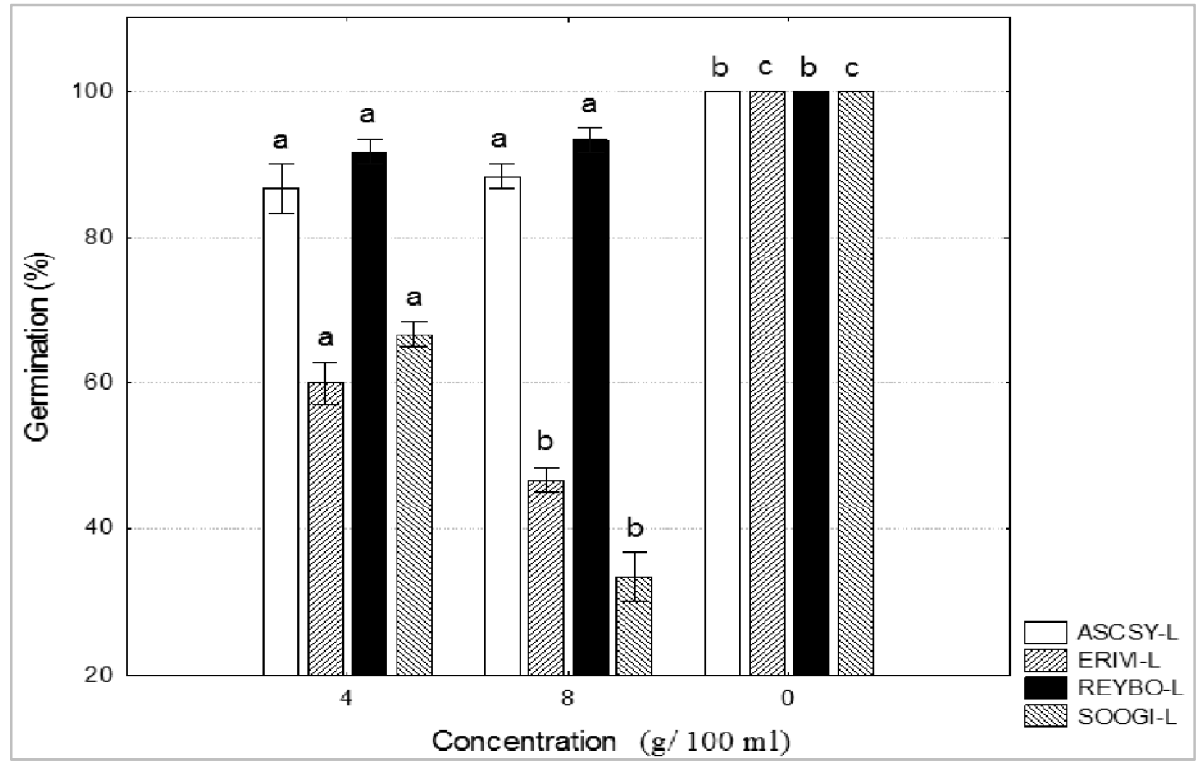

Source: Szilágyi (2017)

Note: small letters show the statistical differences based on Mann-Whitney U- test $(\mathrm{p}<0.05)$.

\section{CONCLUSION}

Based on the present findings, the invasive plants leaf and stem extract seems to exhibit allelopathic potential on local cress varieties by decreasing germination percentages. Biomass allocations of cress (L. sativum) germination were significantly affected by the invasive plants leaf and stem extract. The higher concentrations showed usually the better effect.

\section{ACKNOWLEDGEMENTS}

The publication is supported by the EFOP 3.6.1$16-2016-00022$ project. The project is co-financed by the European Union and the European Social Fund.

I would like to express my thanks to Dr. Antal Nagy for his useful advices in biometric tests. 


\section{REFERENCES}

Asghari, J.-Tewari, J. P. (2007): Allelopathic Potentials of Eight Barley Cultivars on Brassica juncea (L.) Czern. and Setaria viridis (L.) p. Beauv. Journal of Agricultural Science and Technology. 9: 165-176.

Baličević, R.-Ravlić, M.-Živković, T. (2015): Allelopathic effect of invasive species giant goldenrod (Solidago gigantea AIT.) on crops and weeds. Herbologia. 15. 1: 19-29.

Galzina, N.-Šcepanovic, M.-Gorsic, M.-Turk, I. (2011): Allelopathic effect of Abutilon theophrasti Med. on lettuce, carrot and red beet. Herbologia. 12. 2: 125-131.

Ketskeméty L.-Izsó L.-Könyves T. E. (2011): Bevezetés az IBM SPSS Statistics programrendszerbe. Artéria Stúdió Kft. Budapest. 579.
Macias, F. A. (1995): Allelopathy in the Search for Natural Herbicide Models. [In: Inderjit, K. et al. (eds.) Allelopathy: Organisms, Processes and Applications.] ACS Symposium Series 582. American Chemical Society. Washington D.C. 310-329.

Qasem, J. R.-Foy, C. L. (2001): Weed allelopathy, its ecological impact and future prospects. Journal of Crop Production. 4. 2: 43-119.

Ravlić, M.-Baličević, R. (2015): Allelopathic effect of scentless mayweed extracts on carrot. Herbologia. 15. 1: 11-18.

Rice, E. L. (1984): Allelopathy. $2^{\text {nd }}$ edition. Academic Press. Orlando. Florida. USA. 